\title{
An Empirical Investigation of the Critical Factors Affecting Students' Satisfaction in EFL Blended Learning
}

\author{
Jinxiu Wu \\ The Affiliated School of Peking University Wuhan Experimental School, Wuhan, China \\ Wenyu Liu \\ School of Foreign Languages, Dalian University of Technology, Dalian, China
}

\begin{abstract}
The present study intended to examine to what extent students are satisfied with EFL (English as a Foreign Language) blended learning and identify factors affecting students' satisfaction in EFL blended learning. This study used SPSS (Statistical Package for Social Science) and questionnaire as research instrument. Data was collected from 360 first-year non-English major undergraduates and postgraduates in Dalian University of Technology (DUT). The findings were: 1. In general, students showed positive attitude towards EFL blended learning model. They are greatly satisfied with this model and willing to study in EFL blended learning environment. 2. Postgraduate students showed higher satisfaction than undergraduate students. 3. Learning climate, perceived enjoyment, perceived usefulness, system functionality, social interaction, content feature and performance expectation are significantly related to students' satisfaction in EFL blended learning. This study provided more evidence for study on students' satisfaction in EFL blended learning in China. Additionally, constructive suggestions for English Teaching in China were put forward so as to give full play to the advantages of blended learning.
\end{abstract}

Index Terms-EFL blended learning, students' satisfaction, factors

\section{INTRODUCTION}

Traditional mode of classroom teaching invariably play the dominated role in teaching. With the advancement and innovation of information and technology, teaching terms such as distance education, online-learning or web-based learning were put forward. Although they shed light on teaching practice, there also exist some disadvantages. The educators are therefore triggered to seek a better and more effective learning environment that integrates the merits of traditional teaching and online-learning to stimulate even enhance teaching and learning process. Consequently, a novel educational concept called blended learning was developed and regarded as the most promising learning approach. (Graham, 2006). Chances are that the combination of both traditional environment and online environment integrates the merits of two approaches ideally. Indeed, blended learning enjoys a wealth of advantages for instance: instructional richness, access to knowledge content, social interaction, personal agency, cost effectiveness and ease of revision (Osguthorpe \& Graham, 2003).

With the advent of blended learning, many colleges and universities start to put blended learning method into teching practice because it is an increasingly prevalent methodology in effective course delivery. Once the blended learning is employed, additional questions also arise. Are the students willing or reluctant to accept this new learning approach? Do students perceive this new approach as positive or negative ? Then some scholars embarked on figuring out how students view or perceive blended learning (Akkoyunlu \& Soylu, 2006; Giannousi, Vernadakis, Derri, Maria, Michalopoulos \& Kioumourtzoglou, 2009; Abdulrasool, Mishra \& Khalaf, 2010). Researches indicated that most EFL students show positive attitude towards EFL blended learning. (Al-Jarf 2007; Harrington, 2010; Adas \& Shmais, 2011). In Chinese higher education, blended e-learning is only at an early stage. (Zhao, 2008). It is significant to know what chinese students think of this brand-new approach. Numerous domestic scholars studied how Chinese student perceive blended learning environment (Gao, 2007; Zhao, 2008; Chen, 2010; Zhao \& Yuan, 2010). However, only few studies specifically discussed factors affecting students' satisfaction in blended learning, especially in EFL blended learning. Much as scholars have study on it (McDonald, 2004; Aska, Altun, Ilgaz, 2008; Ahmed, 2010; Wu, Tennyson, Hsia, 2010; Zhao \& Yuan, 2010), their researches are quite limited and less comprehensive. Therefore, in-depth and comprehensive studies are demanded to find the best answers.

This research, from the students' perspective, attempts to figure out the critical factors that exert influence on students' satisfaction in blended learning and aims to establish a tentative model under the guidance of Social Cognitive Theory, Theory of Planned Behavior and Technology Acceptance Model to account for causal relationship between those factors and the students' satisfaction in blended learning. In short, this study intends to seek answers to questions as follows: 
1. What do students think of blended learning environment? Are they willing to adopt EFLblended learning?

2. What factors affect students' satisfaction in EFL blended learning environment?

Meanwhile, it is with the hope that the findings of this research will provide insight into developing more effective learning system and shed light on blended teaching practice in current English teaching environment.

\section{LiterATURE REVIEW}

\section{A. Blended Learning}

Though the name of blended learning has been widely used in literature. there are still some alternative names such as mixed learning, hybrid learning and blended e-learning. Various definations of blended learning are exsited in literature. The definitions vary from different scholars.

It is pointed out that blended learning concentrates on perfectly realizing learning objectives by utilizing the suitable personal learning method to watch the best learning style to transfer the appropriate learning skills to the potential student at the correct time. (Singh, 2003). Blended learning is the integration of the advantages of both traditional leaning method and e-learning, so it can display professors' guidance and develop students' initiatives in the meantime. (He, 2004). Blended learning could be simply defined as a desirable e-learning environment with traditional learning. That is to say, bleneded learning takes advantage of various delivery methods to perfectly achieve the course objectives (Akkoyunlu \& Soylu, 2006). Graham regarded blended learning as the combination of traditional face-to-face learning and e-learning (Graham, 2006).

In general, blended learning refers to a pedagogical approach that combines multiple learning delivery means with traditional classroom teaching to perfect teaching efficiency and effectivness. In this research, blended learning is to depict students' learning through traditional classroom teaching with an online EFL self-access system. The EFL self-access system is a software environment developed by DUT that provides English learning materials and resources and self-learning management for students.

\section{B. Students'Satisfaction}

Satisfaction has become a gauge to evaluate training effectiveness in company and learning effectiveness in teching. It has been often used as one of the important parameter to judge students' attitude in resarches related to learning and assess learning effectiveness in academic institution. Students' satisfaction a vital indicator to estimate teaching effectiveness in a blended learning. (Akkoyunlu \& Soylu, 2006). Even though blended learning has been acknowledged as a crucial term to evaluate learning process, the concept is still complex to define and measure.

Knowles deemed that learning satisfaction represents that students are content with current learning. Joyful or delightful attitude means satisfaction. (Knowles, 1970). Long mantained that learning satisfaction means students' positive attitude or feeling during the learning process (Long, 1989). LaPointe and Guawardena offered their definition of blended learning which highlighted students' intention for follow-up learning: a positive or negative emotional experience to the learning environment and an in-depth thought for follow-up involvement in learning activities (LaPointe \& Guawardena, 2004). Students' satisfaction has been defined as the integration of learners' attitudes and perceptions that come from combinating all the benefits that learners expect to gain from interaction with the blended e-learning system (Wu, Tennyson, Hsia, 2010 ).

Several factors which influence students' satisfaction in blended learning have been identified. Jacquelin McDonald (2004) indicated that compatibility with learning style and perceived usefulness were two important causes for satisfaction while perceived risk to study performance and time-consuming print were undesirable factors for satisfaction. Petek Askar and Arif Altun Hale Ilgaz (2008) confirmed there are six factors related to learner satisfaction: learner-learner and learner-teacher interaction, online environment, technical support, printed materials and face to face environment. Hassan M. Selim Ahmed (2010) used instructor characteristics, information technology infrastructure and organizational and technical support to assess hybrid e-learning acceptance. Jen-Her Wu, Robert D. Tennyson, Tzyh-Lih Hsia (2010) pointed out six factors which influence students' satisfaction in blended learning: computer self efficacy, performance expectations, system functionality, content feature, interaction and learning climate. Guodong Zhao \& Shuai Yuan (2010) pointed out that students' satisfaction is closely related to e-learning adaptability, perceived usefulness, timely response from the teachers, perceived ease of use and course applicability.

\section{Factors Involved in This Study}

1. Self-efficacy and Performance Expectation

Social cognitive theory which was put forward by Bandura (1986) is well received. It is a great theory to explain and predict human behavior. Self-efficacy and Performance Expectation are two critical elements in Social Cognitive Theory. In this study, self-efficacy can be defined as students' accessment of their abilities to organize and implement activities required to specific performance, it is not only related to the skills one posesses but also the assessment of what one enable to do with skills one possess. Performance expectations can be defined as students' anticipation concerning ideal rewards after certain behavior. It is no doubt that students are willing to do what will assist them to obtain desirable achivement in study as they hoped.

2. Perceived Behavioral Control and Subjective Norm 
Theory of Planned Behavior deals with the relationship between attitudes and behavior(Ajzen, 1980). Ajzen put forward this theory for explaining human behavior. Perceived behavioral control and subjective norm are two key concepts. In this study, perceived behavioral control is students' percetpion of ease or difficulty of acting certain behavior. In other words, it means students' perceptions of internal and external conditions to perfom certain behavior. Internal behavioral conditions include students' skills and knowledge, while external behavioral conditions contain the resources and opportunities available to students for carrying out certain behavior. Subjective norm refers to students' perception of social normative pressures, or relevant others' beliefs that he or she should or should not perform such behavior. Many students choose to use self-access learning system frequently on the ground that their teachers or classmate recommend and encourage them to take advantage of it.

3. Perceived usefulness, Perceived ease of Use and Perceived Enjoyment

Davis proposed the Technology Acceptance Model (TAM) in 1989. The model has been widespreadly applied to explain user acceptance research of various technologies. There are two important concepts of TAM. They are perceived usefulness and perceived ease of use. In this study, perceived usefulness can be defined as the degree to which students perceive that involving in blended learing would improve their learning performance. Perceived ease of use can be defined as the degree to which students perceived that involving in blended learning would be free from effort and easy to operate. Once EFL learners enjoy usefulness and ease in blended learing environment such as improving their learning performance and learning efficiency, helping them to interact with their classmates and teachers more conveniently, they could possibly adopt blended learning and feel satisfied with blended learning.

Davis et al. (1992) considered perceived enjoyment as the intrinsic motivation. Perceived enjoyment was defined as "the extent to which the activity of using the computer is perceived to be enjoyable in its own right, apart from any performance consequences that may be anticipated" (Davis et al., 1992). It has been confirmed that perceived enjoyment places emphasis on the pleasure and inherent positive feeling from specific behavior. Venkatesh (2000) defined it as the degree to which using a specific system is enjoyable and pleasant regardless of any consequences due to system use. In this study, perceived enjoyment can be defined as studnets' rich entertainment and enjoyable expeience in EFL blended learning. Because blended learning offers students fun and pleasure, EFL students can enjoy themselves in blended learning environment and be willing to accept it from the bottom of heart.

4. System Functionality, Content Feature, Social interaction and Learning Climate

Jen-Her Wu, Robert D. Tennyson, Tzyh-Lih Hsia (2010) defined blended e-learning in terms of technological environment and social environment. Technological environment is composed of system functionality and content feature. In this study, system functionality is defined as flexible access to learning and assessment function in EFL blended learning system. Content feature can be defined as the traits and manifestation or presentation of learning contents in blended learning system. Social environment includes social interaction and learning climate. Social interactions refer to interactions among students themselves, the interactions between teachers and students, and the cooperation in learning. Learning climate refers to a positive and pleasant learning atmosphere that makes learning easy and relaxing.

\section{RESEARCH MODEL}

Drawing upon The Research Model for Student Learning Satisfaction in the BELS Context (Wu, Tennyson, Hsia, 2010) and other relevant literatures, a new research model was proposed. (see Fig. 1). This model suggested that there are eleven factors associated with student satisfaction: self-efficacy, performance expectation, perceived behavioral control, subjective norms, perceived usefulness, perceived ease of use, perceived enjoyment, system functionality, content feature, social interaction and learning climate.

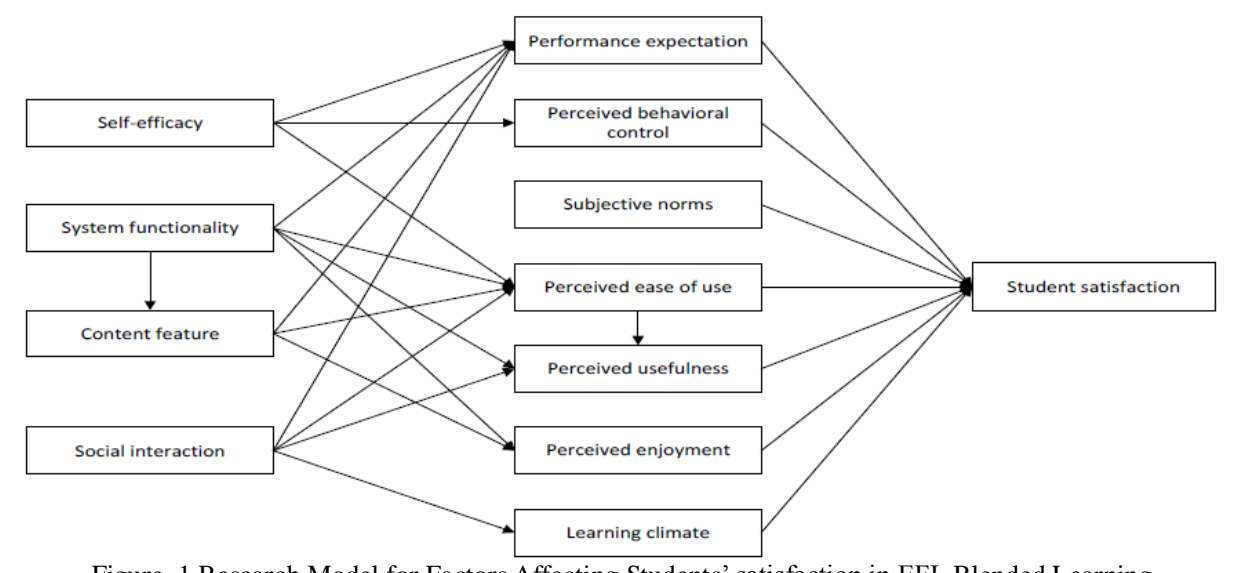

Figure. 1 Research Model for Factors Affecting Students’ satisfaction in EFL Blended Learning 


\section{A. Subject}

360 non-English majors of undergraduates and postgraduates in Dalian University of Technology (DUT) are the research subjects. They are chosen at random. Most of the respondents are males (males account for 63.4\%, females $36.6 \%)$ They ranged in age between 18 and 30 years old. Both undergraduate $(48.4 \%)$ and postgraduate $(51.6 \%)$ participated in this survey. The survey data shows that more than half of students spend 2-4 hours in English study after class. $66.7 \%$ of the subjects have more than 3 years network experience. $65.5 \%$ of the subjects consider their computer skill is intermediate. Besides, almost students could easily have access to computers. $40.9 \%$ of the respondents used computers in school computer room. $47.3 \%$ students have their own computers at dorm. $8.6 \%$ students use computer at home. Only $4.3 \%$ students went to the internet bar. 88.2\% students spend 1-3 hours in self-access English Learning system every week.

\section{B. Instrument}

Based on the above research model and related study, a blended learning satisfaction questionnaire was designed. The questionnaire includes two parts. The first part deals with the subjects' basic information. The second part touches on the subjects' understanding of the variables. It includes 37 questions in terms of 11 variables with students' satisfaction as dependent variable. All measures employ a seven-point Likert scale ranging from 1 (not at all true of me) to 7 (very true of me). The construct validity and internal reliability were checked by the statistical software Statistical Package for Social Science (SPSS).

1. Construct Validity

The KMO and Bartlett's test reveals that the KMO measure of sampling adequacy is 0.836 and the significance is 0.000. This confirms that the component analysis is feasible. Thus principal component analysis was employed to test the construct validity. Twelve variables whose eigenvalues are greater than 1.477 are extracted and consistent with the hypothesized construct. The communality of every variable is above 0.501 and 0.849 and the cumulative variance of the twelve variables is $75.084 \%$, which proves that each variable is helpful to find the answers to the questions. (Table 1). As a result, the questionnaire possesses high construct validity according to the data.

2. Internal Reliability

The internal reliability of the questionnaire was assessed by Cronbach's alpha. Table 2 presents the corresponding cronbach's alpha values. The reliability of each construct is larger than the 0.7 threshold. This confirms that the measurement scales are both valid and reliable. Consequently, the questionnaire displays a high internal reliability to some extent.

TABLE 1.

TOTAL VARIANCE EXPLAINED

\begin{tabular}{l|llllll}
\hline \multirow{2}{*}{ Component } & \multicolumn{3}{l}{ Extraction Sums of Squared Loadings } & \multicolumn{3}{l}{ Rotation Sums of Squared Loadings } \\
\cline { 2 - 6 } & Total & \% of Variance & Cumulative \% & Total & \% of Variance & Cumulative \% \\
\cline { 2 - 6 } 1 & 19.444 & 35.352 & 35.352 & 8.351 & 15.184 & 15.184 \\
2 & 4.360 & 7.927 & 43.279 & 6.613 & 12.023 & 27.207 \\
3 & 3.614 & 6.570 & 49.849 & 4.473 & 8.132 & 35.339 \\
4 & 2.317 & 4.218 & 54.063 & 4.180 & 7.600 & 42.939 \\
5 & 2.064 & 3.753 & 57.815 & 3.306 & 6.010 & 48.949 \\
6 & 1.858 & 3.378 & 61.194 & 2.824 & 5.135 & 54.084 \\
7 & 1.711 & 3.112 & 64.305 & 2.412 & 4.386 & 58.470 \\
8 & 1350 & 2.454 & 66.759 & 2.939 & 4.350 & 62.820 \\
9 & 1.271 & 2.310 & 69.069 & 1.938 & 3.524 & 66.344 \\
10 & 1.199 & 2.180 & 71.250 & 1.732 & 3.150 & 69.493 \\
11 & 1.108 & 2.015 & 73.265 & 1.628 & 2.959 & 72.453 \\
$\mathbf{1 2}$ & 1.001 & 1.819 & 75.084 & 1.477 & 2.631 & 75.084 \\
\hline
\end{tabular}

TABLE 2.

RELIABILITY STATISTICS

\begin{tabular}{l|lll}
\hline Construct & Acronym & Items & Cronbach's Alpha \\
\hline Self-Efficacy & SE & 3 & 0.709 \\
Perceived Behavioral Control & PBC & 4 & 0.775 \\
Performance Expectation & PEx & 4 & 0.863 \\
System Functionality & SF & 3 & 0.876 \\
Content Feature & CF & 3 & 0.859 \\
Social Interaction & SI & 3 & 0.772 \\
Subject Norm & SN & 2 & 0.928 \\
Perceived Ease of Use & PEU & 3 & 0.787 \\
Perceived Usefulness & PU & 3 & 0.905 \\
Perceived Enjoyment & PEn & 2 & 0.723 \\
Learning Climate & LC & 3 & 0.880 \\
Students' Satisfaction & SS & 4 & 0.903 \\
\hline Overall & & 37 & 0.940 \\
\hline
\end{tabular}




\section{A. Students'Satisfaction in EFL Blended Learning}

The means and std. deviation of the satisfaction items are presented in Table 3. It is obvious that most students are positive towards blended learning and willing to adopt blended learning. (Mean scores are all above 4). In general, students are satisfied with EFL blended Learning. What's more, postgraduates' mean of satisfaction subscale and total score is greater than that of undergraduates. That is to say, postgraduate students have higher satisfaction in EFL blended learning. The descriptive statistics of the mean and standard deviation of each variable are shown in Table 4.

TABLE 3.

MEANS OF SATISFACTION ITEMS FOR UNDERGRADUATE AND POSTGRADUATE

\begin{tabular}{ll|lllll}
\hline Grade & & Item34 & Item35 & Item36 & Item37 & Total \\
\hline Undergraduate & Mean & 4.8953 & 4.6512 & 4.3779 & 4.9767 & 19.6512 \\
& Std. Deviation & 1.26610 & 1.26830 & 1.40683 & 1.26099 & 4.40831 \\
Postgraduate & Mean & 5.2447 & 5.3138 & 5.3511 & 5.6330 & 22.0106 \\
& Std. Deviation & 1.42316 & 1.34539 & 1.19453 & 1.06895 & 4.11205 \\
\hline Total & Mean & 4.8861 & 5.3194 & 5.4500 & 5.2278 & 20.8833 \\
& Std. Deviation & 1.38670 & 1.20845 & 1.26788 & 1.25265 & 4.41102 \\
\hline
\end{tabular}

TABLE 4.

DESCRIPTIVE STATISTICS OF EACH VARIABLE

\begin{tabular}{l|ll}
\hline Items & Mean & Std. Deviation \\
Self-efficacy & 15.0778 & 3.34623 \\
Perceived Behavioral Control & 21.2556 & 4.64881 \\
Performance Expectation & 20.0753 & 4.81672 \\
System Functionality & 15.0583 & 3.16482 \\
Content Feature & 15.7139 & 2.99095 \\
Social Interaction & 14.8333 & 3.39342 \\
Subject Norm & 10.6333 & 2.28937 \\
Perceived Ease of Use & 15.3139 & 2.88861 \\
Perceived Usefulness & 15.3333 & 3.50646 \\
Perceived Enjoyment & 10.0750 & 2.50068 \\
Learning Climate & 15.4444 & 3.16267 \\
\hline Students'Satisfaction & 21.5028 & 4.40625 \\
\hline
\end{tabular}

\section{B. Correlations between Each Variable}

In order to identify the correlation between each variable, bivariate correlation is conducted on the data collected. The correlation results are shown in Table 5.

TABLE 5.

CORRELATIONS

\begin{tabular}{|c|c|c|c|c|c|c|c|c|c|c|c|c|}
\hline & $S E$ & $P B C$ & $P E x$ & $S F$ & $C F$ & $S I$ & $S N$ & $P E U$ & $P U$ & PEn & $L C$ & $S S$ \\
\hline SE & 1 & & & & & & & & & & & \\
\hline PBC & $.529 * *$ & 1 & & & & & & & & & & \\
\hline PEx & $.346 * *$ & $.447 * *$ & 1 & & & & & & & & & \\
\hline SF & $.225 * *$ & $.296^{* * *}$ & $.301 * *$ & 1 & & & & & & & & \\
\hline CF & $.235 * *$ & $.205^{* *} *$ & $.229 * *$ & $.644 * *$ & 1 & & & & & & & \\
\hline SI & $.172 * *$ & $.299 * *$ & $.200^{* *}$ & $.620 * *$ & $.485^{* *}$ & 1 & & & & & & \\
\hline SN & $.277 * *$ & $.440 * *$ & $.256^{* *}$ & $.472 * *$ & $.530 * *$ & $.618 * *$ & 1 & & & & & \\
\hline PEU & $.356^{* * *}$ & $.294 * *$ & $.312 * *$ & $.393 * *$ & $.518 * *$ & $.326 * *$ & $.412 * *$ & 1 & & & & \\
\hline PU & $.376^{* *}$ & $.215^{* *}$ & $.146^{* *}$ & $.542 * *$ & $.478 * *$ & $.468 * *$ & $.493 * *$ & $.446^{* * *}$ & 1 & & & \\
\hline PEn & $.425 * *$ & $.236 * *$ & $.290 * *$ & $.501 * *$ & $.354 * *$ & $.517 * *$ & $.440 * *$ & $.319 * *$ & $.551 * *$ & 1 & & \\
\hline LC & $.267 * *$ & $.231 * *$ & $.276^{* *}$ & $.685^{* *}$ & $.591 * *$ & $.600 * *$ & $.610^{* *}$ & $.413 * *$ & $.614 * *$ & $.662 * *$ & 1 & \\
\hline SS & $.400 * *$ & $.224 * *$ & $.709 * *$ & $.550 * *$ & $.538 * *$ & $.567 * *$ & $.537 * *$ & $.407 * *$ & $.673 * *$ & $.712 * *$ & $.754 * *$ & 1 \\
\hline
\end{tabular}

According to the data in Table 5, we can easily see that all dependent variables are related to the independent variable satisfaction. Learning climate $\left(\mathrm{r}=0.754^{* *}\right)$ has the highest correlation to the dependent variable students' satisfaction. Perceived behavioral control and student satisfaction show lower correlation $(\mathrm{r}=.224 * *)$. The easy access to computer use and technical support and easy operation of the system for most people may explain this result. However, it is possible that small correlation coefficient could be significant in large-sampled investigation. Other independent variables that significantly correlated with the dependent variables are: self-efficacy $\left(\mathrm{r}=0.400^{* *}\right)$, performance expectation $(\mathrm{r}=0.709 * *)$, system functionality $(\mathrm{r}=0.550 * *)$, content feature $\left(\mathrm{r}=0.538^{* *}\right)$, social interaction $(\mathrm{r}=0.567 * *)$, subjective norm $\left(\mathrm{r}=0.537^{* *}\right)$, perceived ease of use $\left(\mathrm{r}=0.407^{* *}\right)$, perceived usefulness $\left(\mathrm{r}=0.673^{* *}\right)$, perceived enjoyment $(\mathrm{r}=0.712 * *)$.

\section{Regression Analysis}

In order to know whether the 11 independent variables have a significant bearing on students' satisfaction or not as the dependent variables, a linear regression analysis has been conducted. The results of the stepwise regression are 
presented in Table 6, Table 7 and Table 8.

TABLE 6.

COEFFICIENTS

\begin{tabular}{|c|c|c|c|c|c|}
\hline \multirow[t]{2}{*}{ Model } & \multicolumn{2}{|c|}{ Unstandardized Coefficients } & \multirow{2}{*}{$\begin{array}{l}\text { Standardized } \\
\text { Coefficients } \\
\text { Beta }\end{array}$} & \multirow[t]{2}{*}{$\mathbf{t}$} & \multirow[t]{2}{*}{ Sig } \\
\hline & B & Std Error & & & \\
\hline (Constant) & 1.564 & .806 & & 1.942 & .000 \\
\hline $\mathrm{LC}$ & .514 & .068 & .369 & 7.590 & .000 \\
\hline PEn & .508 & .074 & .288 & 6.905 & .000 \\
\hline PU & .350 & .057 & .281 & 6.174 & .000 \\
\hline SF & .256 & .066 & .184 & 3.854 & .000 \\
\hline SI & .132 & .051 & .102 & 2.589 & .010 \\
\hline $\mathrm{CF}$ & .128 & .062 & .087 & 2.080 & .038 \\
\hline PEx & .110 & .035 & .099 & 3.195 & .002 \\
\hline
\end{tabular}

Table 6 lists the regression coefficients of the seven regression models constructed via stepwise regression method. Seven independent variables are significantly related to students' satisfaction: learning climate, perceived enjoyment, perceived usefulness, system functionality, social interaction, content feature and performance expectation. The non-standarized regression equation can be described like this:

$\mathrm{Y}=1.564+0.514 \times$ learning climate $+0.508 \times$ perceived enjoyment $+0.350 \times$ perceived usefulness $+0.256 \times$ system functionality $+0.132 \times$ social interaction $+0.128 \times$ content feature $+0.110 \times$ performance expectation

Obviously, Learning Climate is most influential factor of students' satisfaction in EFL blended learning. It has a great bearing on students' satisfaction in blended learning. Students are willing to participate in blended learning due to its sound learning atmosphere and they perceived that the sound learning atmosphere will improve their academic performance. Perceived Enjoyment is also a crucial factor affecting students' satisfaction. Once they feel this new learning approach is interesting, they will enjoy the learning process in blended learning. They tend to be satisfied with blended learning. When students perceived the system is beneficial to their learning, they are pleased with the powerful learning system. System Functionality presents powerful function of self-access learning system. Students could log in at anytime at anyplace. It provides diverse forms of information and new ways to communicate and interact with teachers and classmates. Students could hand in online exercises and conduct self-assessment. More powerful the system is, more satisfaction students possess. Social interaction is of great importance in the learning process. In traditional class room teaching, the interaction between students and teachers is rather limited. In blended learning, when students have questions after class, they could contact teacher or classmates through E-mails, forum and other forms. Timely feedback made them involved and motivated to learn. It is no doubt that course content is associated with students' satisfaction in blended learning. As long as the course content is well designed, be personalized, easy to understand and clearly display the important learning points, students would have intention to learn this course. Performance expectation also plays a vital role in students' satisfaction. Student have their own learning expectations such as good scores in exam, high learning efficiency, flexible learning schedule, good interaction with classmate and teachers.etc. Only when these learning expectations are satisfied, can they be positive toward blended learning.

Table 7 shows the R Square values, adjusted R square values, and Std. Error of the estimate for each of the four constructs. R2 is a statistic that shows the degree of the regression line approximating the real data points. An R2 of 0.709 means that the regression line is in accordance with the data. And the seven independent models can explain $70.9 \%$ of the variance. The Durbin-Watson value of 1.874 almost reaches 2 . So there is no autocorrelation.

TABLE 7.

MODEL SUMMARY

\begin{tabular}{l|lllll}
\hline Model & $\boldsymbol{R}$ & $\boldsymbol{R}$ Square & $\begin{array}{l}\text { Adjusted } \\
\boldsymbol{R} \text { Square }\end{array}$ & $\begin{array}{l}\text { Std. Error of } \\
\text { the Estimate }\end{array}$ & $\begin{array}{c}\text { Durbin- } \\
\text { Watson }\end{array}$ \\
\hline 1 & $.754^{\mathrm{a}}$ & .569 & .568 & 2.89697 & \\
2 & $.806^{\mathrm{b}}$ & .650 & .648 & 2.61562 & \\
3 & $.828^{\mathrm{c}}$ & .686 & .684 & 2.47813 \\
4 & $.832^{\mathrm{d}}$ & .693 & .690 & 2.45522 \\
5 & $.836^{\mathrm{e}}$ & .699 & .695 & 2.43362 \\
6 & $.840^{\mathrm{f}}$ & .706 & .700 & 2.41139 & \\
7 & $.842^{\mathrm{g}}$ & .709 & .703 & 2.40012 & 1.874 \\
\hline
\end{tabular}

Table 8 shows Model Dimension, Eigenvalue, Condition Index, Variance Proportions calculated via Collinearity Diagnostics. The largest condition index is 27.442 . This proves that no strong colllinerity problem exists. Therefore, we can ignore the effect of multicollinerity. 
TABLE 8.

COLLINEARITY DIAGNOSTICS ${ }^{\mathrm{A}}$

\begin{tabular}{|c|c|c|c|c|c|c|c|c|c|c|}
\hline Model & Eigenvalue & $\begin{array}{l}\text { Condition } \\
\text { Index }\end{array}$ & \multicolumn{8}{|c|}{ Variance Proportions } \\
\hline 1 & 7.817 & 1.000 & .00 & .00 & .00 & .00 & .00 & .00 & .00 & .00 \\
\hline 2 & .062 & 11.188 & .01 & .00 & .01 & .04 & .68 & .00 & .02 & .00 \\
\hline 3 & .035 & 14.967 & .06 & .01 & .50 & .00 & .01 & .02 & .00 & .10 \\
\hline 4 & .026 & 17.437 & .03 & .00 & .01 & .26 & .03 & .00 & .63 & .02 \\
\hline 75 & .023 & 18.512 & .65 & .00 & .08 & .03 & .19 & .08 & .12 & .00 \\
\hline 6 & .015 & 22.996 & .05 & .34 & .00 & .52 & .04 & .12 & .17 & .05 \\
\hline 7 & .012 & 25.532 & .17 & .01 & .01 & .01 & .02 & .59 & .06 & .56 \\
\hline 8 & .010 & 27.442 & .02 & .63 & .39 & .15 & .02 & .20 & .01 & .26 \\
\hline
\end{tabular}

Fig. 2 presents the normal P-P plot of regression standardized residual. The following normal probability plot is also a kind of test of normaly distributed residual error. If the plot forms a 45-degree line, then it is perfect normality. From the figure, it is easy to observe that the actual residual almost forms a 45-degree line. Consequently, this study does not violate the basic assumption of regression. The conclusion is reliable.

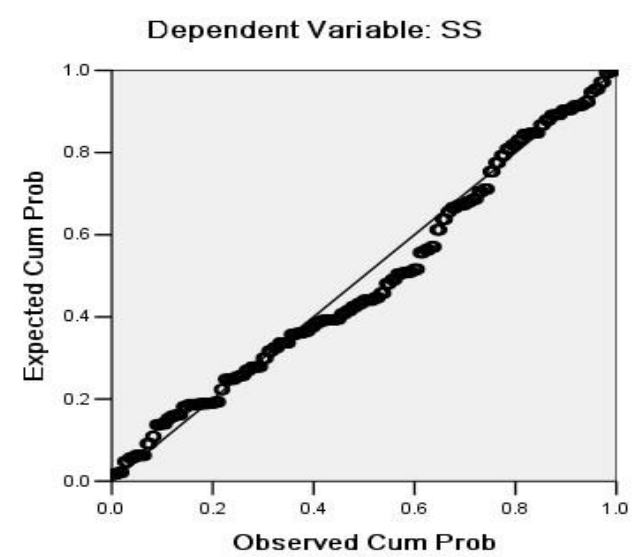

Figure 2. Normal P-P Plot of Regression Standardized Residual

According to the results above, the final model was established.

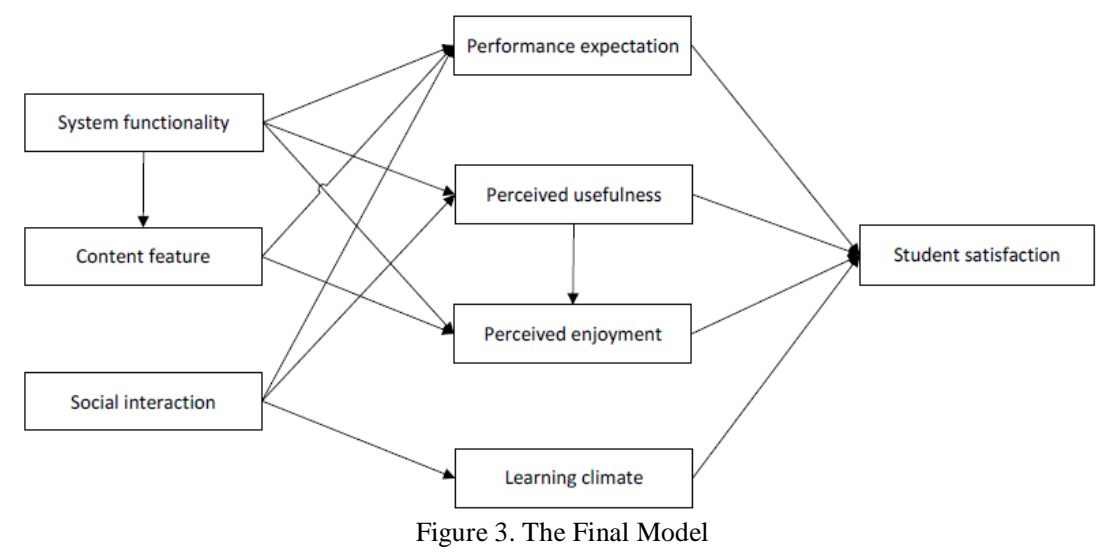

\section{CONCLUSION}

In this study, Social Cognitive Theory, Theory of Planned Behavior and Technology Acceptance Model serve as the theoretical framework to explore to what extent student are satisfied with EFL blended learning and the fundamental factors that influence students' satisfaction in EFL blended learning. EFL blended learning was defined as traditional classroom instruction and Self-access English Learning system. Data were collected through questionnaires from 360 undergraduate and postgraduates of non-English majors in Dalian University of Technology. Valuable findings are gained from the present study: 1. In general, students showed positive attitude towards EFL blended learning model. They are greatly satisfied with this model and willing to study in EFL blended learning environment. 2. Postgraduate students showed higher satisfaction than undergraduate students. 3. Learning climate, perceived enjoyment, perceived usefulness, system functionality, social interaction, content feature and performance expectation are significantly related to students' satisfaction in EFL blended learning.

To increase students' satisfaction in EFL blended learning, the following suggestions are raised. Teachers and 
students should make joint efforts to promote and build up good learning climate. As for the system developer and administrators, they should pay more attention to improve the system interaction and function by devising various and useful contents to increase students' learning interests. With regard to teachers, they should improve their computer skills and provide necessary assistance when students are involved in online learning. Apart from that, teachers should give timely feedback and interact with students frequently and encourage students to learn and participate in group activities by giving participation marks and encourage them to interact with others and share learning experience and exchange ideas. In addition, they need conduct student need analysis and bear students' expectations in mind so as to better design and organize teaching activities and balance the classroom teaching and online teaching activities. Thus students would enjoy the learning process in blended learning and be satisfied with blended learning.

This study still has certain limitations. First, even though this research indicated that a majority of students' are satisfied with EFL blended learning in Dalian University of Technology, some negative answers deserve further research attention. Secondly, our results were merely obtained from one questionnaire in Dalian University of Technology, the samples need to be enlarged to make the conclusion more representative. Third, other possible factors that affect students' satisfaction in EFL blended learning need to be deeply explored. Fourth, other research methods should be employed such as SEM (Structure Equation Model), LISREL, EQS, PLS. or neural network to examine cause-effect relationship among variables with more convincing figures.

\section{ACKNOWLEDGEMENT}

This research was supported by Liaoning BaiQianWan Talents Program (2011921067) and the Graduate School of Dalian University of Technology.

\section{APPENDIX 英语混合学习学生满意度调查问卷}

您好!本问卷是针对英语混合学习（课堂学习+网络自主学习系统学习）情况的调查, 本问卷所获取的信息只 用于科学研究, 不会对您本人产生任何的影响, 希望您根据自己实际的情况认真填写,谢谢您的配合与帮助!

第一部分: 个人基本信息

请您如实填写如下个人信息, 在相应的答案代码上画：“小”。

\begin{tabular}{|ll|l|}
\hline 1. & 性别: & $1=$ 男 $2=$ 女 \\
\hline 2. & 年龄 & $1=18-22$ \\
& & $2=23-25$ \\
\hline 3. & 入学年份 & $3=26-30$ \\
\hline $4 . \quad$ 年级: & $1=2010 \quad 2=2009 \quad 3=2008$ \\
& & $4=2007 \quad 5=2006 \quad 6=2005$ 及以前 \\
& & $1=$ 非外语专业本科生 \\
& & $2=$ (非外语专业) 英语辅修 \\
& & $3=$ 外语专业本科生 \\
& & $4=$ 双学位学生 \\
\hline 5. & 你每周用于英语学习的时间大概是多少 $?$ & $5=$ 英强学生 \\
& & $6=$ 硕士研究生 \\
& & $7=$ 博士研究生 \\
\hline & & $2=$ 只是在课堂上的时间 \\
& & $3=$ 课外 5 - 7 小时 \\
\hline 6. & 你的网络经验 & $4=$ 课外 8 - 10 小时 \\
& & $5=10$ 小时以上 \\
\hline 7. & 你的计算机水平 & $1=1$ 年以下 \\
& & $2=1-3$ 年 \\
& & $3=3$ 年以上 \\
\hline 8. & 你上网的主要场所 & $1=$ 熟练 \\
& & $2=$ 般 \\
& & $3=$ 熟练 \\
\hline 9. & 你每周用于英语自主学习系统的时间是 & $1=$ 学校机房 \\
& & $2=$ 宿舍 \\
& & $3=$ 吧 \\
& & $4=$ 家里 \\
\hline
\end{tabular}


的数字量度来回答问题, 如果你认为叙述非常符合你, 就在数字 7 上画: “小”。如果该叙述根本不符合你的情况, 请画数字 1 。如果叙述或多或少符合你，请在 1 到 7 之间的数字中画一个最符合你情况的。

\begin{tabular}{|c|c|c|c|c|c|c|c|}
\hline $\begin{array}{lllclll}7 & 6 & 5 & 4 & 3 & 2 & 1 \\
\text { 符合 } & & & \begin{array}{c}1 \\
\text { 完全符合 } \longleftarrow\end{array} & & & \end{array}$ & & & & & & & \\
\hline $\begin{array}{lll}1 . & \text { 我相信我可以很快接受并适应混合学习（课堂学习+ } & \text { 网络自主系 } \\
\text { 统学习）的学习模式。 } & \\
\end{array}$ & 7 & 6 & 5 & 4 & 3 & 2 & 1 \\
\hline 2.＜wide>不需要太多支持帮助,我也能顺利使用英语自主学习系统。 & 7 & 6 & 5 & 4 & 3 & 2 & 1 \\
\hline 使用过程中如果遇到技术操作问题, 我相信自己可以很好地处理。 & 7 & 6 & 5 & 4 & 3 & 2 & 1 \\
\hline 混合学习将会提高我的学习成绩。 & 7 & 6 & 5 & 4 & 3 & 2 & 1 \\
\hline 混合学习将会提高我的学习效率。 & 7 & 6 & 5 & 4 & 3 & 2 & 1 \\
\hline 混合学习将会使我的学习更加丰富和多样化。 & 7 & 6 & 5 & 4 & 3 & 2 & 1 \\
\hline 混合学习将会加强我与老师同学间的交流与沟通。 & 7 & 6 & 5 & 4 & 3 & 2 & 1 \\
\hline 我会操作英语网络自主学习系统。 & 7 & 6 & 5 & 4 & 3 & 2 & 1 \\
\hline 我具备进行网络自主系统学习的基本知识。 & 7 & 6 & 5 & 4 & 3 & 2 & 1 \\
\hline 我拥有进行网络自主系统学习的必要资源, 比如:电脑,网络等。 & 7 & 6 & 5 & 4 & 3 & 2 & 1 \\
\hline $\begin{array}{l}11 . \quad \text { 技术支持和指导服务（如新手入门指导培训、模拟操作、过程演示） } \\
\text { 在系统使用说明中均有展示。 }\end{array}$ & 7 & 6 & 5 & 4 & 3 & 2 & 1 \\
\hline $\begin{array}{l}\text { 12. 系统可以不限时不限地反复登录进行学习, 这使我的学习活动更加灵活 } \\
\text { 自由。 }\end{array}$ & 7 & 6 & 5 & 4 & 3 & 2 & 1 \\
\hline $\begin{array}{l}\text { 13. 系统运用语音、文字、图片、视频等多媒体技术, 提供全面实用的学 } \\
\text { 习资源,满足不同学习者需求。 }\end{array}$ & 7 & 6 & 5 & 4 & 3 & 2 & 1 \\
\hline 14. $\quad$ 网络自主学习系统可以让我自主安排学习活动。 & 7 & 6 & 5 & 4 & 3 & 2 & 1 \\
\hline 15. $\quad$ 课程内容个性化, 容易理解。 & 7 & 6 & 5 & 4 & 3 & 2 & 1 \\
\hline 16. $\quad$ 目前所学的英语课程适合用网络自主系统学习。 & 7 & 6 & 5 & 4 & 3 & 2 & 1 \\
\hline 17. 课程学习任务清楚明了, 充分展示了学习重点与难点活动安排合理。 & 7 & 6 & 5 & 4 & 3 & 2 & 1 \\
\hline $\begin{array}{l}\text { 18. 我和同学们能够通过学习系统中的邮件、讨论区、留言板等随时讨论 } \\
\text { 学习内容并交换各自意见,巩固所学。 }\end{array}$ & 7 & 6 & 5 & 4 & 3 & 2 & 1 \\
\hline $\begin{array}{l}\text { 19. 我会主动参与课堂讨论,积极参与老师组织的网上教学活动, 及时获得 } \\
\text { 老师关于作业或考试反馈。 }\end{array}$ & 7 & 6 & 5 & 4 & 3 & 2 & 1 \\
\hline 20. 混合学习是促进我和同学及老师之间的互动交流很好的学习方式。 & 7 & 6 & 5 & 4 & 3 & 2 & 1 \\
\hline 混合学习模式下, 学习氛围非常好。 & 7 & 6 & 5 & 4 & 3 & 2 & 1 \\
\hline 混合学习模式下, 学习氛围越浓厚, 我越愿意参与。 & 7 & 6 & 5 & 4 & 3 & 2 & 1 \\
\hline 混合学习良好的互动氛围促进我的学习。 & 7 & 6 & 5 & 4 & 3 & 2 & 1 \\
\hline 对我来说，学习系统的操作非常简单。 & 7 & 6 & 5 & 4 & 3 & 2 & 1 \\
\hline 系统导航清晰布局合理，操作方便 & 7 & 6 & 5 & 4 & 3 & 2 & 1 \\
\hline 26. 网络自主学习系统中的学习资源容易查阅, 方便下载。 & 7 & 6 & 5 & 4 & 3 & 2 & 1 \\
\hline $\begin{array}{l}\text { 27. 利用网络自主学习系统的混合学习,能加深我对课堂学习内容的理解, } \\
\text { 使我更快地完成课程学习任务掌握学习内容。 }\end{array}$ & 7 & 6 & 5 & 4 & 3 & 2 & 1 \\
\hline 28. 混合学习促进我的自主学习,使我能更好安排学习活动,管理学习进程。 & 7 & 6 & 5 & 4 & 3 & 2 & 1 \\
\hline 混合学习模式激发我的学习兴趣,给我更多学习信心。 & 7 & 6 & 5 & 4 & 3 & 2 & 1 \\
\hline $\begin{array}{l}\text { 30. 老师对利用英语自主学习系统态度很积极,鼓励我们进行英自主系统学 } \\
\text { 习。 }\end{array}$ & 7 & 6 & 5 & 4 & 3 & 2 & 1 \\
\hline 周围同学系统学习的参与情况影响我使用系统学习的情况。 & 7 & 6 & 5 & 4 & 3 & 2 & 1 \\
\hline 我很喜欢并很享受丰富有趣的混合学习过程。 & 7 & 6 & 5 & 4 & 3 & 2 & 1 \\
\hline 混合学习 (课堂学习+网络自主学习系统学习) 是一种令人愉快的经历。 & 7 & 6 & 5 & 4 & 3 & 2 & 1 \\
\hline 实施英语混合学习是非常明智的。 & 7 & 6 & 5 & 4 & 3 & 2 & 1 \\
\hline 混合学习满足我的学习需求, 是非常有效的学习方式。 & 7 & 6 & 5 & 4 & 3 & 2 & 1 \\
\hline 整体而言，我对英语混合学习模式持积极肯定态度。 & 7 & 6 & 5 & 4 & 3 & 2 & 1 \\
\hline 总的来说, 我对这种学习模式很满意, 打算今后更多参与混合学习。 & 7 & 6 & 5 & 4 & 3 & 2 & 1 \\
\hline
\end{tabular}

\section{REFERENCES}

[1] Abdulrasool, S. Mishra, \& R. Khalaf, H. (2010). Teachers' and students' attitudes towards traditional and computer assisted blended teaching and learning processes in mechanical engineering subject area. The proceedings of 10th IEEE International Conference on Computer and Information Technology (CIT 2010), 1436-1441.

[2] Adas, D. \& Shmais, W. A. (2011). Students' perceptions towards blended learning environment using the OCC. An-Najha Univ. J. Res. (Humanities), 25.6, 1681-1710.

[3] Ajzen, I. \& Fishbein, M. (1980). Understanding attitudes and predicting social behavior. Englewood Cliffs, NJ: Prentice Hall.

[4] Akkoyunlu, B. \& Soylu, M. Y. (2006). A study on students' views on blended learning environment. Turkish Online Journal of Distance Education, 7.3, 43-56.

[5] Aska, P. Altun, A. \& Ilgaz, H. (2008). Learner satisfaction on blended learning. E-leader Krakow.

[6] Bandura, A. (1986). Social foundations of thought and action: a social cognitive theory. Englewood Cliffs, NJ: Prentice Hall.

[7] Chen, S. H. (2010). Study on model satisfaction in supporting blended learning. Computer Education, 20, 155-159.

[8] Davis, F. D. Bagozzi, R. P. \& Warshaw, P. R. (1992). Extrinsic and intrinsic motivation to use computers in the workplace. 
Journal of Applied Social Psychology, 22, 1111-1132.

[9] Gao, Z. (2007). The effect analysis of blended learning in college English teaching. Modern Distance Education Research, 4. $88,40-42$.

[10] Giannousi, M. Vernadakis, N. Derri, V. Michalopoulos, M. \& Kioumourtzoglou, E. (2009). Students' satisfaction from blended learning instruction. TCC proceedings, 61-68.

[11] Graham, C. R. (2006). Blended learning system: Definition, current trends, future directions. In C. J. Bonk \& C. R. Graham (Eds.). Handbook of blended learning. San Francisco, CA: Pfeiffer, 3-21.

[12] Guodong Zhao \& Shuai Yuan. (2010). Key Factors of Effecting Blended Learning Satisfaction: A Study on Peking University Students. Hybrid learning Lecture Notes in Computer Science. Volume 6248, pp 282-295.

[13] Harrington, M. A. (2010). Problematizing the hybrid classroom for ESL/EFL students. The Electronic Journal for English as a Second Language, 14.3, 1-13.

[14] He, K. H. (2004). View education technology development from blended learning. E-Eduacation, 3, 1-6.

[15] Knowles, M. S. (1970). The modern practice of adult education: Andragogy versus earning and the learning organization: examining the connection between the individual and the learning environment. Human Resource Development Quarterly, 9.4, 365-375.

[16] LaPointe, D. K. \& Gunawardena, C. N. (2004). Developing, testing and refining a model to understand the relationship between peer interaction and learning outcomes in computer mediated conferencing. Distance Education, 25.1, 83-106.

[17] Long, H. B (1985). Contradictory expectations: Achievement and satisfaction in adult learning. Journal of Continuing Higher Education, 33.3, 10-12.

[18] McDonald, J. (2004). Students' satisfaction with a hybrid course offering: An Australian case study. The Proceedings of International Conference on Computers in Education 2004, 1041-1050.

[19] Ng, P. \& Tsoi, R. H. L. (2008). A study on the students' perception of adopting blended learning at sub-degree level. In J. Fong, R. Kwan, F. L. Wang (Eds). Hybrid Learning: A new frontier. HongKong, 78-88.

[20] Osguthorpe. R. T. \& Graham, C. R. (2003). Blended learning environments: Definitions and directions. The Quarterly Review of Distance Education, 4.3, 227-233.

[21] Reima, A. (2007). Blended learning in EFL: What college students say. The Proceedings of 12th TCC 2007 Worldwide Online Conference, "Blending Reality and Multimedia in Ubiquitous Learning".

[22] Selim, A. H. M. (2010). Empirical research: Hybrid E-learning acceptance model: Learner perceptions. Decision Sciences Journal of Innovative Education, 8.2, 313-346.

[23] Singh, H. (2003). Building effective blended learning programs. Education Technology, 43.6, 51-64.

[24] Venkatesh, V. (2000). Determinants of perceived ease of use: Integrating control, intrinsic motivation, and emotion into the technology acceptance model. Information Systems Research, 11.4, 324-365.

[25] Wu, J. H. Tennyson, R. D. \& Hsia, T. L. (2010). A study of student satisfaction in a blended e-learning system environment. Computers \& Education, 55, 155-164.

[26] Jianhua Zhao. (2008). An Examination of Students' Perception of Blended E-learning in Chinese Higher education. Lecture Notes in Computer Science.

Jinxiu Wu received her master's degree in Dalian University of Technology. Her research interests are ESL learning strategy and computer assisted language learning. The paper is based on a project sponsored by Dalian University of Technology.

Wenyu Liu received his Ph.D. from Dalian University of Technology and now is a Professor in the School of Foreign Languages at Dalian University of Technology. He has been teaching since 1993. From 2009 to 2010, he worked as a Fulbright research scholar at the University of Minnesota Twin cities, the U.S.A. His research interests are teaching English as a second or foreign language, and computer assisted language learning. 